\title{
BALANCED SCORECARD: IMPLEMENTASI INTERAKSIONAL AGENCY THEORY DAN STAKEHOLDER THEORY DALAM MANAJEMEN PERGURUAN TINGGI
}

\author{
Oleh: \\ Sukirno DS \\ Jurusan Pendidikan Akuntansi Universitas Negeri Yogyakarta
}

\begin{abstract}
Abstrak
Lemahnya kualitas pengelolaan sumber daya yang dimiliki perguruan tinggi di Indonesia dapat berakibat terhadap munculnya persoalan rendahnya daya saing sumber daya bangsa. Rendahnya ranking perguruan tinggi dibandingkan perguruan tinggi lain di dunia, rendahnya kualitas sumber daya manusia dibandingkan dengan negara lain, dan tingginya angka pengangguran di Indonesia dapat menjadi indikator masih diperlukannya pendekatan jitu dalam manajemen sumber daya perguruan tinggi.

BSC adalah sebuah pendekatan yang dapat dipilih perguruan tinggi untuk mengelola sumber daya dalam mewujudkan visi dan misinya. Implementasi BSC di perguruan tinggi dapat menjadi sebuah pendekatan strategis dan operasional yang efektif dan efisien apabila diimplementasikan dengan prosedur yang benar dengan melibatkan shareholer dan stakeholer. BSC menawarkan sebuah cara bagi perguruan tinggi untuk mencapai tujuan secara komprehensif, berimbang, dan terintegrasi antara kinerja keuangan dan non-keuangan, kinerja jangka pendek dan jangka panjang, serta kinerja internal dan kinerja eksternal.
\end{abstract}

Kata kunci: Balance Score Card, Agency Theory, Stakeholder Theory, Perguruan Tinggi

\section{PENDAHULUAN}

Perguruan tinggi memiliki tugas menyiapkan anak bangsa menjadi pemimpin di masa yang akan datang. Dalam menyiapkan anak bangsa, perguruan tinggi dituntut untuk menjadi sebuah lembaga pendidikan yang berkualitas global. Ada beberapa hal yang harus di perhatikan berhubungan dengan kualitas perguruan tinggi diantaranya proses pembelajaran, sumber daya manusia, kemahasiswaan, kurikulum, sarana dan prasarana, suasana akademik, keuangan, penelitian dan publikasi, pengabdian masyarakat, tata pamong, manajemen lembaga, sistem informasi dan kerjasama (Taufiq, 2012). Secara kuantitas, menurut Ketua Umum Asosiasi Dosen Indonesia, Profesor Armey Arief, saat ini jumlah Perguruan Tinggi Negeri (PTN) dan Perguruan Tinggi Swasta (PTS) di Indonesia menduduki peringkat tertinggi di dunia. Angka perguruan tinggi kita telah mencapai angka 4.350 (dengan jumlah penduduk sekitar 250 juta jiwa) lebih besar dibandingkan China yang hanya memiliki 2.824 kampus dengan jumlah penduduk lebih dari 1.4 miliar.

Dalam lamannya Ristekdikti (2016) dilaporkan bahwa ditinjau dari angka human development index (HDI), Indonesia memiliki peringkat jauh lebih rendah $(0,689$ masuk kelompok medium dengan kenaikan rerata per tahun 0,003) daripada China (0,738 dengan kenaikan rerata per tahun 0,010). Lebih jauh, sampai sekarang belum satupun perguruan tinggi di Indonesia yang menduduki peringkat di bawah 500 dunia di Webometric ataupun The Times Higher Education World University Rankings (THEWUR).

Dewan Perwakilan Rakyat (DPR) mencatat berbagai kendala mendasar yang ada dalam dunia perguruan tinggi yaitu (Anonim, 2012): pertama, masih rendahnya kualitas dan kwantitas pendidik. Masalah ini merupakan persoalan krusial yang harus segera diatasi, karena akan berdampak signifikan terhadap lulusan 
yang dihasilkan. Salah satu yang akan terdampak adalah indeks pembangunan manusia Indonesia yang selama ini dinilai masih rendah. Terkait dengan ini, dibutuhkan perhatian yang serius dalam rangka meningkatkan kualitas pendidik. Para dosen harus secara berkelanjutan melakukan update kemampuan dan ilmunya, sesuai perkembangan ilmu pengetahuan dan teknologi yang terus berjalan melalui pendidikan dan pelatihan. Di samping itu, jumlah dosen antar prodi maupun antaruniversitas di Indonesia masih timpang baik di Jawa apalagi di Luar Jawa.

Kedua, belum memadainya fasilitas pendidikan. Hingga kini masih banyak perguruan tinggi yang belum memiliki fasilitas pendidikan yang lengkap, sehingga proses pembelajaran dan hasil lulusan menjadi kurang optimal. Perlu diingat bahwa tanpa fasilitas yang memadai dan relevan dengan kebutuhan, maka hasil pendidikan tidak akan optimal. Hal ini pada umumnya terjadi di berbagai fakultas yang membutuhkan alat peraga dan alat praktik dalam proses pembelajaran seperti fakultas kedokteran, fakultas teknik, fakultas peternakan, fakultas pertanian, dan lain sebagainya.

Ketiga, masalah efektivitas pendidikan. Efektivitas pendidikan terkait erat dengan kualitas sumber daya manusia yang dihasilkan oleh pendidikan tinggi. Namun kenyataan yang sangat memprihatinkan adalah, bahwa di Indonesia, hingga kini masih banyak penyelenggaraan perguruan tinggi yang belum efektif, sehingga hanya sedikit perguruan tinggi Indonesia yang masuk pada ranking atas perguruan tinggi di tingkat dunia dan bahkan tingkat Asia. Kenyataan ini menunjukkan betapa parahnya kualitas pendidikan tinggi di kebanyakan perguruan tinggi Indonesia, dan tentu saja hal ini berimplikasi pada sumber daya manusia yang dihasilkan.

$$
\text { Keempat, mahalnya biaya }
$$
pendidikan. Sebagaimana kita ketahui bersama, hingga kini masyarakat masih harus menanggung banyak biaya, sehingga hanya golongan masyarakat mampu yang dapat membiayai pendidikan anaknya di jenjang pendidikan ini. Meskipun Pemerintah menyediakan beasiswa untuk mahasiswa dari keluarga tidak mampu, namun jumlahnya hanya sedikit. Dampak akhir dari kenyataan ini adalah ketidakadilan dalam memperoleh hak atas pendidikan.

Kelima, masalah pengangguran terdidik. Pengangguran terdidik terkait dengan kualitas perguruan tinggi. Banyaknya lulusan perguruan tinggi yang tidak dapat segera memasuki dunia kerja, apalagi menciptakan lapangan kerja sendiri, merupakan permasalahan krusial dalam perguruan tinggi di Indonesia. Berdasarkan pengamatan, pengangguran terdidik di Indonesia terus mengalami peningkatan sejak beberapa tahun terakhir, sementara jumlah penganggur tidak terdidik makin turun. Dengan melonjaknya jumlah pengangguran intelektual maka tugas pemerintah untuk menciptakan lapangan kerja juga akan semakin susah. Perguruan tinggi belum sepenuhnya memberikan pencerahan kepada masyarakat melalui nilai dan manfaat pendidikan itu sendiri (Musyaddad, 2013). Lebih jauh ditulis, rendahnya kualitas lulusan merupakan salah satu bukti bahwa pendidikan di Indonesia belum secara optimal dikembangkan.

Keenam, link and match antara perguruan tinggi dan kebutuhan akan sumber daya manusia di lapangan kerja pesonal maupun organisasional. Perguruan tinggi bagai berjalan dengan iramanya sendiri, sementara kondisi riil di lapangan kurang diperhatikan secara matang. Akhirnya perguruan tinggi tidak mampu menjadi faktor yang penting dalam upaya peningkatan kesejahteraan masyarakat. Perguruan tinggi belum mampu sepenuhnya mampu melahirkan sumberdaya manusia yang layak diterima di lapangan kerja yang ada, dan perguruan tinggi juga belum mampu menghasilkan entrepreneur yang memiliki keberanian dan kemandirian.

Persoalan lain yang berpengaruh terhadap manajemen perguruan tinggi di 
Indonesia adalah penilaian kinerja dan penghargaan. Kedua faktor itu menjadi pemicu buruknya budaya kerja dan kinerja perguruan tinggi (Njanja, et.al., 2013; Akinbowale, et.al., 2014). Penilaian kinerja perguruan tinggi masih dominan menggunakan ukuran-ukuran kuantitatif seperti data demografi mahasiswa dan dosen, pendaftar, IPK, ranking kelas, persentase diterima (acceptance rate), jumlah dosen pensiun, ratio dosen mahasiswa, beban mengajar, jumlah buku perpustakaan, jumlah publikasi dan sebagainya (Rubent, 1999). Menurut Rubent (1999), ukuran kuantitatif semisal memiliki banyak kelemahan karena tidak mampu merepresentasikan status terkini dari lembaga, faktor kesuksesan lembaga, visi dan misi, serta strategi lembaga. Ukuran kualitas proses pembelajaran dan lulusan (output) serta dampaknya pada lingkungan (outcome) merupakan indikator-indikator penting yang harus juga menjadi pertimbangan dalam pengambilan keputusan terkait manajemen perguruan tinggi.

Konsep Balanced Scorecard (BSC) merupakan sebuah model sistem pengukuran kinerja yang menawarkan kerangka komprehensif dan berimbang serta menjadi sebuah solusi yang baik dalam pengukuran kinerja (Wibisono, 1999). BSC menghubungkan entitas, visi, misi, strategi, nilai-nilai inti, dan target yang dirancang untuk memotivasi organisasi ke arah perbaikan secara terus menerus serta memfasilitasi organisasi agar dapat menghasilkan pengambilan keputusan yang efektif dan efisien (Wibisono, 1999).

Menjelang abad 21 dunia perguruan tinggi menghadapi tantangan yang cukup serius dalam perkembangannya. Akhir abad 21 yang ditandai dengan derasnya arus globalisasi menyebabkan pengetahuan (sebagai core business perguruan tinggi) menjadi produk unggulan yang dominan dan memiliki peran signifikan dalam masyarakat. Ciri spesifik dari masyarakat pengetahuan adalah masyarakat yang secara mandiri memiliki kemampuan berkomunikasi dan bekerjasama secara lintas budaya dalam dunia yang tak berbatas (Wibisono, 1999).

Menyoal problematika yang dihadapi bangsa dalam hal perguruan tinggi, penulis tertarik untuk membuat kajian permasalahan ini dan mengemukakan tema BSC, mediator maksimalisasi pemuasan kepentingan pemangku kepentingan (stakeholer theory) dan pemegang saham (agency theory) perguruan tinggi di Indonesia.

\section{Stakeholder Theory}

Stakeholder merupakan individu, sekelompok manusia, komunitas atau masyarakat baik secara keseluruhan maupun secara parsial yang memiliki hubungan serta kepentingan terhadap perusahaan. Individu, kelompok, maupun komunitas dan masyarakat dapat dikatakan sebagai stakeholder jika memiliki karakteristik seperti mempunyai kekuasaan, legitimasi, dan kepentingan terhadap perusahaan (Budimanta dkk., 2008). Dalam konteks perguruan tinggi mahasiswa, orang tua, pemerintah, peneliti pendidikan, masyarakat adalah pemangku kepentingan yang harus diperhitungkan dalam manajemen perguruan tinggi.

Perguruan tinggi merupakan bagian dari sistem sosial yang ada dalam sebuah wilayah baik yang bersifat lokal, nasional, maupun internasional berarti perguruan tinggi merupakan bagian dari masyarakat secara keseluruhan. Masyarakat sendiri menurut definisinya bisa dijelaskan sebagai kumpulan peran yang diwujudkan oleh elemen-elemen (individu dan kelompok) pada suatu kedudukan tertentu yang peran-peran tersebut diatur melalui pranata sosial yang bersumber dari kebudayaan yang telah ada dalam ma syarakat (Budimanta dkk, 2008).

Perguruan tinggi dalam hal ini merupakan bagian dari beberapa elemen yang membentuk masyarakat dalam sistem sosial yang berlaku. Keadaan tersebut kemudian menciptakan sebuah hubungan timbal balik antara perguruan tinggi dan 
para stakeholder yang berarti perguruan tinggi harus melaksanakan peranannya secara dua arah untuk memenuhi kebutuhan sendiri maupun stakeholder lainnya dalam sebuah sistem sosial. Oleh karena itu, segala sesuatu yang dihasilkan dan dilakukan oleh masing-masing bagian dari stakeholder akan saling mempengaruhi satu dengan yang lainya sehingga tidaklah tepat jika perguruan tinggi menyempitkan pengertian stakeholder hanya dari sisi ekonominya saja (Budimanta dkk, 2008).

Konsep tanggung jawab sosial perusahaan telah mulai dikenal sejak awal 1970 an, yang secara umum dikenal dengan stakeholder theory artinya sebagai kumpulan kebijakan dan praktik yang berhubungan dengan stakeholder, nilai-nilai, pemenuhan ketentuan hukum, penghargaan masyarakat dan lingkungan, serta komitmen dunia usaha untuk berkontribusi dalam pembangunan secara berkelanjutan. Stakeholder theory dimulai dengan asumsi bahwa nilai (value) secara eksplisit dan tak dipungkiri merupakan bagian dari kegiatan usaha (Freeman et al., dalam Anwar, 2013). Teori stakeholder mengatakan bahwa perguruan tinggi bukanlah entitas yang hanya beroperasi untuk kepentingan sendiri namun harus memberikan manfaat bagi stakeholdernya. Dengan demikian, keberadaan suatu perguruan tinggi sangat dipengaruhi oleh dukungan yang diberikan oleh stakeholder (Ghozali dan Chariri, 2007).

Stakeholder pada dasarnya dapat mengendalikan atau memiliki kemampuan untuk mempengaruhi pemakaian sumber-sumber ekonomi yang digunakan olebh perguruan tinggi (Waryanti, 2009). Daya tawar stakeholder dapat berupa kemampuan untuk membatasi pemakaian sumber ekonomi (modal dan tenaga kerja), akses terhadap media yang berpengaruh, kemampuan untuk mengatur perguruan tinggi, atau kemampuan untuk mempengaruhi produk yang dihasilkan perguruan tinggi (Brown dan Deegan, 1998). Jadi kemudian muncullah statement bahwa ketika stakeholder mengendalikan sumber ekonomi (input dari sistem pendidikan yang berupa kurikulum, dosen, mahasiwa, sararana dan prasarana) yang penting bagi perguruan tinggi, maka perguruan tinggi mestinya bereaksi dengan cara-cara yang memuaskan keinginan stakeholder (Ullman, 1982).

\section{Agency Theory}

Sarwoko (2010) menyebutkan bahwa teori agensi lahir dari pemikiran yang mengkaji penyerahan otoritas dari pemilik (owners) ke manajer (agen). Manajer adalah orang yang tidak dapat dipercaya penuh dan memilki tujuan yang terpisah dengan tujuan principal. Agency theory didefiniskan sebagai "a "nexus of contracts" between different resource suppliers. Two parties are central to agency theory; principals, who supply capital, and agents, who manage the day to day affairs of the firm (Proffitt, 2000).

Kajian permasalahan yang muncul antara principal-agent banyak dilakukan sejak awal kemunculannya oleh banyak pakar dan peneliti bidang akuntansi, pemasaran, politik dan sosiologi (Fama, 1980). Teori keagenan mendasarkan pada beberapa asumsi. Pertama, asumsi tentang sifat manusia. Asumsi ini menekankan bahwa manusia selalu mengutamakan kepentingan dirinya sendiri (self interest), selalu berupaya untuk menghindari risiko (risk-aversion), dan manusia dianggap memiliki rasionalitas yang terbatas (bounded rasionality). Agen adalah manusia dengan demikian memiliki kelemahan. Agen jarang sekali mempunyai tujuan yang diatur secara konsisten. Agen dipandang tidak selalu mengejar tujuannya secara sistematis, membuat keputusan dengan informasi yang tidak lengkap, dan jarang sekali melakukan suatu penelitian yang mendalam untuk mencari alternatif (Sarwoko, 2010).

Kedua, asumsi tentang organisasi, dalam asumsi ini organisasi dianggap selalu terjadi konflik tujuan antar pihak yang berkepentingan (principal dan agent), adanya informasi yang tidak simetris 
(asymetric information) antara principal dan agent, dan efisiensi sebagai kriteria efektivitas. Ketiga, asumsi informasi adalah bahwa informasi sebagai komoditas yang dapat diperjualbelikan (information as a purchasable commodity). Dalam konteks pidato ini, agen adalah pengelola perguruan tinggi sedangkan prinsipal adalah pemerintah atau donatur atau pemilik atau sponsor yang menanamkan modalnya di perguruan tinggi.

Fenomena hubungan keagenan menjadi semakin menarik perhatian, karena memunculkan permasalahan tersendiri terutama isu moral hazard dan adverse selection Moral hazard ini berhubungan dengan masalah biaya yang dikeluarkan oleh prinsipal untuk melindungi kepentingan prinsipal dari keputusan-keputusan agen dikarenakan asumsi bahwa agen memiliki informasi yang lebih dibandingkan dengan prinsipal. Dalam kaitan untuk menghindari masalah tersebut, misalnya, perlu dibangun kemudian upaya-upaya untuk mengurangi kemungkinan bahwa agen (pengelola perguruan tinggi) akan merongrong kepentingan prinsipal karena agen bekerja untuk kemakmuran pribadi dan kelompoknya dengan mengabaikan kepentingan lembaga dan prinsipalnya. Agency theory di sini kemudian memfokuskan pada upayanya untuk monitor agen dengan membangun strategi dan kerangka arah (guidelines) agar monitoring efektif (Sarwoko, 2010)..

Secara garis besar, agency theory ditujukan untuk memecahkan dua permasalahan yang dapat terjadi dalam hubungan keagenan berikut ini (Eisenhardt, 1989).

"......Agency Theory is concerned with resolving two problem s that can occur in agency relationship. The first is the " agency problem 'that arises when a) the desires or goals of the principal and agent conflict and (b) it is difficult or expensive for the principal verify what the agent actually doing. The problem here is that the principal cannot verify that the agent has behaved appropriately. The second is the problem of risk sharing that arises when the principal and agent have different attitudes toward risk. The problem here is the principal and the agent may prefer different actions because of the different risk preferences.

Secara sepihak dapatlah diaktakan agency theory lebih fokus kepada kepentingan keuntungan finansial para pemegang saham (prinsipal) dengan mengendalikan agen sebaik-baiknya semisal dengan ajaran shareholder theory. Sebagai penutup subbagian ini, Barney \& Hansen (1994) pernah menyatakan bahwa "shareholer theory is the dominant theory espoused and theory - in - use in business schools and in the vast majority of businesses in capitalist economies".

\section{Balance Score Card}

Agency theory dan turunannya shareholder theory memiliki tujuan untuk memaksimalisasi keuntungan finansial para pemegang saham atau para prinsipal sedangkan kepentingan pemangku kepentingan menjadi tujuan keduanya (Barney \& Hansen, 1994).

Stakeholder theory mengutamakan jalinan sosial yang baik dengan para pemangku kepentingan sedangkan keuntungan finansial hanyalah dampak pengiringnya. Lebih jauh Barney \& Hansen (1994) menjelaskan relasi sosial yang baik dengan pemangku kepentingan "assists companies in developing valuable intangible assets which can be sources of competitive advantage because such assets can differentiate a company from its competitors."

Stakeholder theory berfokus pada kemakmuran sosial para pemangku kepentingan perguruan tinggi, agency theory fokus kepada kemakmuran pemodal (pemerintah, masyarakat, mahasiswa atau sponsor), sedangkan BSC menawarkan keseimbangan pemuasan kepentingan kedua pihak. Lebih jauh BSC merupakan kerangka konseptual bagi organisasi yang dapat 
digunakan untuk menerjemahkan tujuan strategis ke dalam seperangkat indikator kinerja. Pendekatan klasik berfokus pada kinerja operasional dan penggunaan ukuran keuangan dalam mengukur kinerja organisasi, sedangkan BSC menawarkan pendekatan komprehensif dan lebih baik dengan cara menghubungkan strategi organisasi dengan tujuan terukur dalam empat perspektif: keuangan, pelanggan, internal proses, dan pembelajaran dan pertumbuhan (Brown, 2010).

Balanced Scorecard terdiri dari dua suku kata yaitu kartu nilai (scorecard) dan berimbang (balanced). Hansen \& Mowen (2000: 397) memberikan pengertian BSC adalah

"a strategic management system that defines a strategic based responsibility accounting. The BSC translates an organization's mission and strategy into operasional objectives and performance measures for four different perspective: the financial perspective, the customer perspective, the internal business process perspective, and the learning and growth (infrastructure) perspective".

BSC merupakan alat untuk membantu organisasi dalam pemetaan strategi peningkatan kinerja dan membangun jaringan dengan berbagai level dalam organisasi. Selain itu, BSC dapat digunkan untuk mengidentifikasi hubungan sebab-akibat antarberbagai faktor. Peta strategi BSC itu akan menjadi cetak biru rencana organisasi (Brown, 2012).

Gambar berikut ini representasi BSC menerjemahkan visi, misi, strategi institusi secara berimbang ke dalam empat aspek dimensi finansial-non finansial, jangka pendek-panjang, dan internal-eksternal.

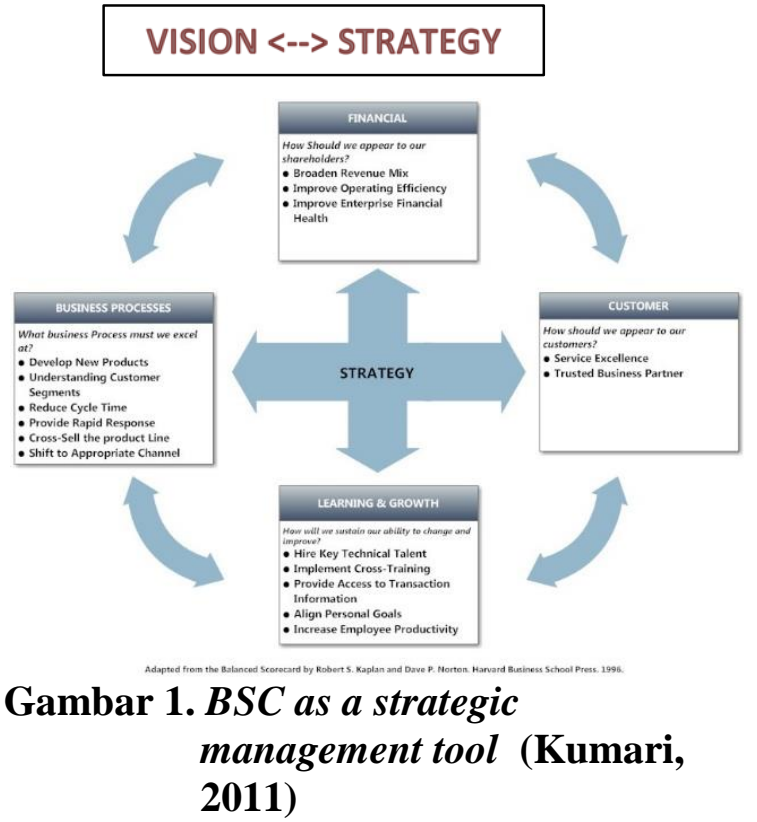

Sofwan (2012) menjelaskan, kartu nilai digunakan untuk mengukur kinerja riil yang dibandingkan dengan kinerja yang direncanakan, serta dapat digunakan sebagai evaluasi dan dasar penentuan penghargaan. Berimbang (balanced) artinya kinerja diukur secara berimbang dari dua aspek: keuangan dan non-keuangan, jangka pendek dan jangka panjang, intern dan ekstern. Karena itu jika kartu digunakan untuk merencanakan skor yang hendak diwujudkan di masa depan, maka harus memperhitungkan keseimbangan antara pencapaian kinerja keuangan dan nonkeuangan, kinerja jangka pendek dan jangka panjang, serta antara kinerja internal dan eksternal.

BSC membantu organisasi dalam menerjemahkan visi menjadi programprogram kerja beserta anggaran yang dapat diukur dengan baik melalui key performance indicator (KPI). BSC juga dilengkapi dengan strategy map yang digunakan untuk melakukan komunikasi kepada seluruh elemen dalam suatu organisasi maupun luar organisasi atau pihak-pihak yang berkepentingan (stakeholders) sehingga organisasi dapat mengimplementasikan strategi dengan lebih mudah (Triyanti dkk., 2013).

Mengadaptasi pendapat Singgih dkk. (2001), Sofwan (2012), (Kumari, 2011) dan 
Widiastuti dan Immanuel (2015), empat perspektif BSC dalam konteks manajemen perguruan tinggi yang komprehensif, berimbang, dan terintegrasi dapat dijabarkan sebagai berikut.

\section{Perspektif Pelanggan}

Scorecard pada perspektif ini digunakan untuk menjawab pertanyaan "How should we appear to our customers?" Sasarannya adalah memberikan kepuasan kepada mahasiswa, orang tua dan pemangku kepentingan terkait lainnya atas pelayanan yang diberikan. Untuk memperoleh loyalitas pelanggan dan mampu menawarkan lini produk yang lengkap. Ukuran yang dipakai dapat berwujud pangsa pasar, akuisisi pelanggan, retensi pelanggan, profitabilitas pelanggan, dan kepuasan pelanggan. Kualitas layanan terdiri atas lima dimensi yaitu:

a. Tangibility (Tampilan fisik dan media komunikasi).

Indikator dari perspektif layanan phisik perguruan tinggi dapat berupa lokasi, tempat belajar, fasilitas komputer, fasilitas perpustakaan, ruang dosen, alat belajar, ruang tunggu, penampilan karyawan dosen, tempat parkir, anjungan mahasiswa.

b. Reliability (Pelayanan yang terpercaya).

Indikator perspektif dari reliabilitas layanan perguruan tinggi adalah penawaran mata kuliah, jadwal perkuliahan dan ujian, metode mengajar, penilaian perkuliahan, perhitungan indeks prestasi, buku wajib dan buku tambahan, bimbingan KRS.

c. Responsiveness (Ketanggapan dalam memberikan layanan).

Indikator yang menggambarkan layanan perguruan tinggi yang tanggap adalah administrasi PMB, penyelesaian surat keterangan, fasilitas layanan, keluhan proses administrasi, keluhan kebersihan. d. Assurance (Jaminan pelayanan). Indikator terhadap jaminan kualitas layanan perguruan tinggi dapat berupa keramahan dosen dan karyawan, kemampuan dan pengetahuan dosen dan karyawan, sopan santun dosen dan karyawan

e. Empathy (sikap peduli dan penuh perhatian).

Indikator terkait dengan sikap peduli dan perhatian dapat berupa karyawan mengenal mahasiswa, dosen mengenal mahasiswa, karyawan dan dosen memberikan pelayanan.

2.Perspektif Pembelajaran dan Pertumbuhan Scorecard pada perspektif ini menjawab pertanyaan "Can we continue to improve and create value?" Sasaran perspektif ini adalah mengidentifikasi infrastruktur yang harus dibangun dalam menciptakan pertumbuhan dan peningkatan kinerja jangka panjang yang sumber utamanya datang dari manusia, sistem dan prosedur, indeks kepuasan karyawan, kualias dosen melalui tingkat pendidikan, kepangkatan, pengalaman mengajar, usia dosen, kualitas karyawan administrasi melalui usia, tingkat pendidikan, dan pengalaman bekerja. Pengukuran perspektif pembelajaran dan pertumbungan dapat berasal dari tingkat kepuasan pegawai atau tingkat perputaran pegawai dan produktivitas karyawan.

\section{Perspektif Proses Bisnis Internal}

Scorecard pada perspektif ini menjawab pertanyaan "What must we excel at?". Sasarannya berkaitan dengan pengembangan layanan akademik yang berkelanjutan. Untuk mengukur variabel kinerja proses bisnis internal didasarkan pada dua indikator, yaitu inovasi dan layanan purna jual atau wisuda. Indikator inovasi diukur dengan indikator aplikasi komputer yang diadopsi, laboratorium yang dikembangkan, unit atau lembaga keuangan dan non keuangan yang 
dimiliki, pembayaran uang kuliah. Indikator layanan purna jual dapat berwujud kesempatan menjadi dosen dan bursa tenaga kerja, perkembangan jumlah jurusan atau program studi, keaktifan dosen, jumlah penggunaan metode pembelajaran, penggunaan media pembelajaran, proporsi kurikulum dan mata kuliah, pelaksanaan lokakarya kurikulum, jumlah lulusan, jumlah IPK rata-rata lulusan, dan penambahan fasilitas fisik. Ciri-ciri proses bisnis internal yang berhasil dapat berupa merek / image yang kuat dan terkenal, memiliki kualitas lulusan / produk yang baik, memberikan pengalaman pendidikan yang menarik.

\section{Perspektif Keuangan}

Scorecard pada perspektif ini menjawab pertanyaan "How do we look at shareholders?" Kinerja perguran tinggi menurut perspektif ini akan dipengaruhi oleh kelihaiannya dalam mengatur pengeluaran yang dilakukan perguruan tinggi sesuai dengan yang anggaran, menyusun dan menetapkan pengeluaran gaji dan upah, pengeluaran belanja barang, pengeluaran untuk belanja modal, sumber penerimaan dari hibah, PNBP, APBN, dan sebagainya. Ukuran yang dipakai dapat berupa kenaikan nilai investasi / penerimaan, peningkatan profitabilitas, peningkatan jumlah bauran sumber penerimaan, dan penurunan pengeluaran.

Keempat aspek BSC dapat pula dijabarkan bebasis level organisasional diadaptasikan dari Kumari (2011) dan Ronchetti (2006) dalam bentuk matrik berikut ini.

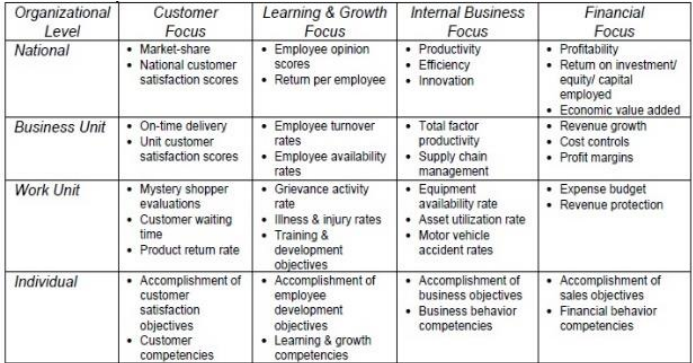

Gambar 2. Matrix of BSC on

Organization Levels

Langkah-langkah dalam implementasi empat aspek BSC dalam organisasi secara strategis dijabarkan oleh Kumari (2011) sebagai berikut.

1. The major objectives are to be set for each of the perspectives.

2. Measures of performance are required to be identified under each of the objectives which would help the organization to realize the goals set under each of the perspectives. These would act as parameters to measure the progress towards the objectives.

3. The next important step is the setting of specific targets around each of the identified key areas which would act as a benchmark for performance appraisal.

4. The appropriate strategies and the action plans that are to be taken in the various activities should be decided so that it is clear as to how the organization has decided to pursue the pre-decided goals. Because of this reason, the Balanced Scorecard is often referred to as a blueprint of the company strategies.

Langkah-langkah institusi menerjemahkan visi, misi hingga pengukuran kinerja dan evaluasi secara matrik perkalian level organisasi dan empat elemen BSC dapat disajikan dalam bentuk gambar berikut ini. 


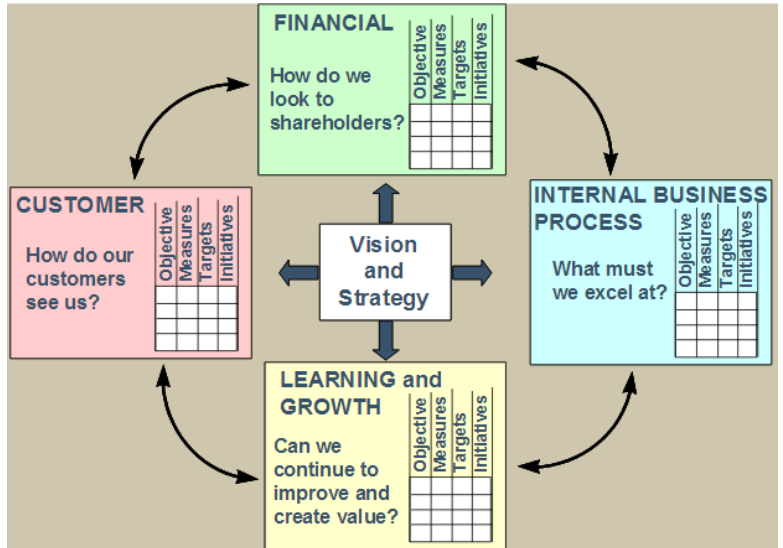

Gambar 3. Methodology Overview of Balanced Scorecard Elaboration (Hansen et.al., 2009; Kumari, 2011)

\section{Organisasi menggunakan BSC} untuk menghasilkan berbagai proses manajemen yang lebih baik (Kaplan dan Norton, 1996). Implementasi BSC dapat memperjelas dan menerjemahkan visi dan strategi, mengomunikasikan dan mengaitkan berbagai tujuan dan ukuran strategis, merencanakan, menetapkan sasaran, dan menyelaraskan berbagai inisiatif strategis, serta meningkatkan umpan balik dan pembelajaran strategi (Lestari, 2013).

\section{Implementasi Balance Score Card Dalam Pembangunan Daya Saing}

Pengelolaan perguruan tinggi yang mengabaikan aspek kinerja keuangan dan non-keuangan, kinerja jangka pendek dan jangka panjang, serta antara kinerja bersifat internal dan kinerja eksternal akan segera hilang dari peredaran. Untuk menghambat tumbuhnya pemikiran dan budaya yang menyimpang dari arus keberimbangan, BSC menawarkan solusi melalui penjabaran visi dan strategi ke dalam tujuan konkret dan terorganisasi di sepanjang jalur empat perspektif finansial, pelanggan, proses internal, dan pembelajaran dan pertumbuhan.

Mengadaptasi tulisan Hermawan (2005), Lestari (2013), dan Mulyadi (2007) untuk mengimplementasikan BSC di perguruan tinggi, beberapa langkah yang harus dilakukan adalah:

1. menilai sumber daya yang dimiliki, merumuskan visi dan misi perguruan tinggi secara partisipatif dengan melibatkan para stakeholder internal dan eksternal (objectives). Penilaian sumber daya meliputi analisis kekuatan, kelemahan, kesempatan dan ancaman terhadap organisasi yang dapat dilakukan dengan menggunakan SWOT analysis yang akan mempengaruhi kinerja perguruan tinggi.

2. perumusan tujuan, sasaran, dan strategi masing-masing unit atau program studi berdasarkan visi dan misi perguruan tinggi (initiatives). inisiatif strategis merupakan program -program yang harus dilakukan untuk memenuhi salah satu atau berbagai tujuan strategis. Sebelum menetapkan inisiatif, yang harus dilakukan adalah menentukan target. Target merupakan suatu tingkat kinerja yang diinginkan (Lestari, 2013).

3. merumuskan ukuran-ukuran visi, misi, dan sasaran perguruan tinggi dan unit (measures). Ukuran-ukuran itu disebtu sebagai indikator kunci sukses perguruan tinggi. Indikator kunci atau KPI (Key Performance Indicator) dikembangkan berdasarkan hasil analisis kondisi perguruan tinggi yang terdiri dari dua kelompok yaitu KPI upaya (input) yang mencakup proses/program dan KPI luaran (output).

4. implementasi inisiatif strategis yang telah digariskan dalam aturan penganggaran (RKPT, RKT) dan rencana strategis perguruan tinggi dan unit di bawahnya (implementation).

5. pengukuran kinerja perguruan tinggi dan unit terkait (performance measurement). 
6. evaluasi strategis dan operasional untuk mendapatkan umpan balik dan perbaikan strategi perguruan tinggi di masa yang akan datang (evaluation).

Untuk memberikan arah implementasi BSC di perguruan tinggi, dengan mengadaptasi tulisan Suryaputra dan Yuniawati (2012), berikut ini diberikan sebuah contoh matrik tabulasi perspektif pelanggan BSC sebuah perguruan tinggi.

Tabel 1.Penjabaran Perspektif Pelanggan BSC Perguruan Tinggi

\begin{tabular}{|c|c|c|c|c|c|c|}
\hline Pelanggan & Objective & Measure & Initiative & Target & Actual & $\begin{array}{c}\text { Tren } \\
\text { d / } \\
\text { Ket }\end{array}$ \\
\hline $\begin{array}{l}\text { Mahasisw } \\
\text { a }\end{array}$ & $\begin{array}{l}\text { Merekrut } \\
\text { mahasiswa } \\
\text { yang } \\
\text { berkualitas } \\
\text { tinggi }\end{array}$ & $\begin{array}{l}\text { Jumlah dan } \\
\text { kualitas } \\
\text { mahasiswa }\end{array}$ & $\begin{array}{l}\text { Promosi dengan } \\
\text { berbagai media }\end{array}$ & $\begin{array}{l}\text { Rerata tingkat } \\
\text { ketetatan } \\
0,5 \\
\text { Ada sistem } \\
\text { pendaftaran, } \\
\text { CAT semua } \\
\text { prodi, } \\
\text { pengumunan } \\
\text { online } \\
\text { Mahasiswa } \\
\text { dari semua } \\
\text { propinsi ada }\end{array}$ & $\begin{array}{l}\text { Rerata tingkat } \\
\text { ketetatan } 1,45 \\
\text { Ada sistem } \\
\text { pendaftaran, } \\
\text { CAT hanya } \\
\text { pasca, } \\
\text { pengumunan } \\
\text { online } \\
\text { Mahasiswa } \\
\text { dari semua } \\
\text { propinsi ada }\end{array}$ & OK \\
\hline & $\begin{array}{l}\text { Membangu } \\
\mathrm{n} \\
\text { pengajaran } \\
\text { yang } \\
\text { berkualitas }\end{array}$ & $\begin{array}{l}\text { IPK } \\
\text { mahasiswa }\end{array}$ & $\begin{array}{l}\text { Pendidikan dan } \\
\text { Pelatihan dosen }\end{array}$ & $\begin{array}{l}\text { 100\% dosen } \\
\text { bergelar Dr } \\
\text { Ada pelatihan } \\
\text { PTK dan } \\
\text { Lesson study } \\
\text { Ada pelatihan } \\
\text { pengembanga } \\
\text { n Media } \\
\text { Pembelajaran } \\
\text { di Prodi } 1 \text { th } \\
\text { sekali } \\
\text { Rerata IPK > } \\
3,0\end{array}$ & $\begin{array}{l}\text { Dr baru 13\% } \\
\text { Ada pelatihan } \\
\text { PTK dan } \\
\text { Lesson study } \\
\text { Belum ada } \\
\text { pelatihan } \\
\text { pengembanga } \\
\text { n Media } \\
\text { Pembelajaran } \\
\text { di Prodi 1 th } \\
\text { sekali } \\
\text { Rerata IPK > } \\
3,2\end{array}$ & $\begin{array}{l}\text { LR } \\
\text { OK }\end{array}$ \\
\hline & $\begin{array}{l}\text { Lulusan } \\
\text { yang } \\
\text { berkualitas } \\
\text { tinggi }\end{array}$ & $\begin{array}{l}\text { Gaji awal } \\
\text { alumni } \\
\text { Kualitas dan } \\
\text { jumlah } \\
\text { perusahaan } \\
\text { yang } \\
\text { merekrut } \\
\text { alumni }\end{array}$ & $\begin{array}{l}\begin{array}{l}\text { Pelatihan soft } \\
\text { skill }\end{array} \\
\begin{array}{l}\text { Pelatihan Job } \\
\text { Hunting }\end{array} \\
\begin{array}{l}\text { Penyelenggaraa } \\
\text { n Bursa kerja }\end{array}\end{array}$ & $\begin{array}{l}1 \text { th sekali ada } \\
\text { pelatihan JH } \\
1 \text { th sekali ada } \\
\text { BK }\end{array}$ & $\begin{array}{l}1 \text { th sekali ada } \\
\text { pelatihan JH } \\
1 \text { th sekali ada } \\
\text { BK }\end{array}$ & $\begin{array}{l}\text { OK } \\
\text { OK }\end{array}$ \\
\hline
\end{tabular}




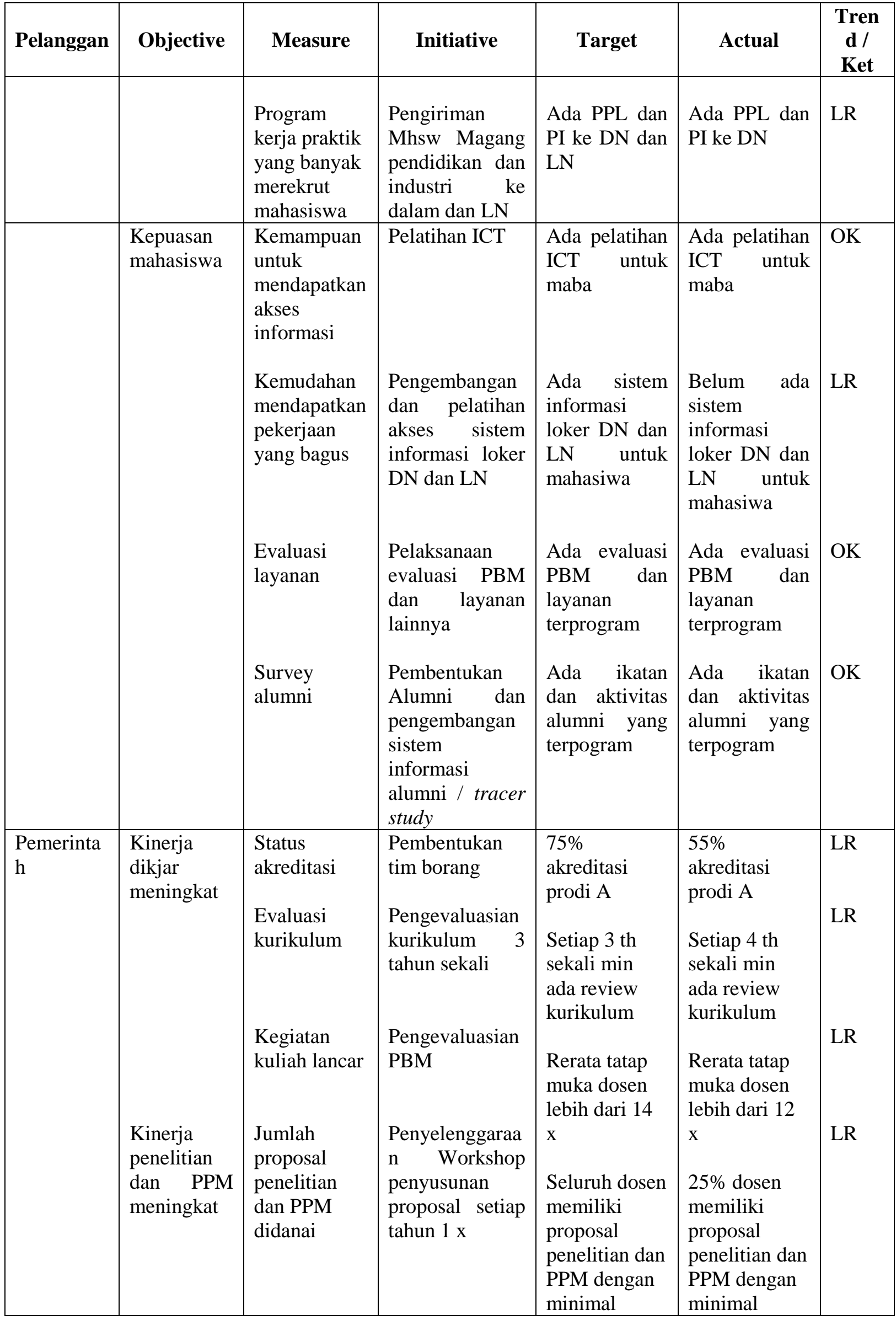




\begin{tabular}{|c|c|c|c|c|c|c|}
\hline Pelanggan & Objective & Measure & Initiative & Target & Actual & $\begin{array}{l}\text { Tren } \\
\text { d / } \\
\text { Ket }\end{array}$ \\
\hline & $\begin{array}{l}\text { Kinerja } \\
\text { luaran } \\
\text { ilmiah } \\
\text { meningkat }\end{array}$ & $\begin{array}{l}\text { Jumlah } \\
\text { HAKI dan } \\
\text { jurnal yang } \\
\text { dipublikasi } \\
\text { nasional dan } \\
\text { internasional }\end{array}$ & $\begin{array}{l}\text { Penyelenggaraa } \\
\mathrm{n} \text { Workshop } \\
\text { penulisan } \\
\text { artikel publikasi } \\
1 \mathrm{x} \text { setahun }\end{array}$ & $\begin{array}{l}\text { melibatkan } 2 \\
\text { mhsw } \\
\text { Seluruh dosen } \\
\text { melakukan } \\
\text { penelitian dan } \\
\text { PPM dengan } \\
\text { minimal } \\
\text { melibatkan } 2 \\
\text { mhsw } \\
\text { 50\% dari } \\
\text { jumlah dosen } \\
\text { dan 25\% } \\
\text { mahasiswa } \\
\text { presentasi dan } \\
\text { pembicara di } \\
\text { konferensi } \\
\text { nasional dan } \\
\text { internasional } \\
\text { 50\% dosen } \\
\text { dan 25\% } \\
\text { mahasiswa } \\
\text { publikasi di } \\
\text { jurnal } \\
\text { nasional dan } \\
\text { atau } \\
\text { internasional }\end{array}$ & $\begin{array}{l}\text { melibatkan } 2 \\
\text { mhsw } \\
25 \% \text { dosen } \\
\text { melakukan } \\
\text { penelitian dan } \\
\text { PPM dengan } \\
\text { minimal } \\
\text { melibatkan } 2 \\
\text { mhsw } \\
10 \% \text { dari } \\
\text { jumlah dosen } \\
\text { dan 1\% } \\
\text { mahasiswa } \\
\text { presentasi dan } \\
\text { pembicara di } \\
\text { konferensi } \\
\text { nasional dan } \\
\text { internasional } \\
\text { 10\% dosen } \\
\text { dan 1\% } \\
\text { mahasiswa } \\
\text { publikasi di } \\
\text { jurnal } \\
\text { nasional dan } \\
\text { atau } \\
\text { internasional }\end{array}$ & LR \\
\hline \multirow[t]{3}{*}{ Pegawai } & \multirow{3}{*}{\begin{tabular}{|l|} 
Keterlibata \\
$\mathrm{n}$ dalam \\
pengambila \\
$\mathrm{n}$ keputusan \\
meningkat \\
\\
\\
Jobdes yang \\
jelas \\
dengan \\
dukungan \\
fasilitas \\
yang baik
\end{tabular}} & $\begin{array}{l}\text { Keterlibatan } \\
\text { pengambilan } \\
\text { keputusan }\end{array}$ & $\begin{array}{l}\text { Penglibatan } \\
\text { pegawai dalam } \\
\text { pengambilan } \\
\text { keputusan }\end{array}$ & $\begin{array}{l}\text { Pegawai } \\
\text { dilibatkan } \\
\text { dalam rapat- } \\
\text { rapat terkait }\end{array}$ & $\begin{array}{l}\text { Pegawai } \\
\text { belum } \\
\text { dilibatkan } \\
\text { dalam semua } \\
\text { rapat-rapat } \\
\text { terkait }\end{array}$ & LR \\
\hline & & $\begin{array}{l}\text { Pendefinisia } \\
\mathrm{n} \text { jobdesk } \\
\text { dan } \\
\text { prosedur } \\
\text { yang tersedia }\end{array}$ & $\begin{array}{l}\text { Perumusan } \\
\text { WS jobdesk } \\
\text { dan prosedur } \\
\text { layanan }\end{array}$ & $\begin{array}{l}\text { Ada jobdesk } \\
\text { dan prosedur } \\
\text { kerja pegawai }\end{array}$ & $\begin{array}{l}\text { Ada jobdesk } \\
\text { dan tapi } \\
\text { prosedur kerja } \\
\text { pegawai } \\
\text { belum jelas }\end{array}$ & LR \\
\hline & & $\begin{array}{l}\text { Ketersediaan } \\
\text { fasilitas / } \\
\text { teknologi } \\
\text { yang } \\
\text { menunjang }\end{array}$ & $\begin{array}{l}\text { Pembangunan } \\
\text { fasilitas dan } \\
\text { penyediaan IT }\end{array}$ & $\begin{array}{l}\text { Ada fasilitas } \\
\text { dan IT yang } \\
\text { layak }\end{array}$ & $\begin{array}{lr}\text { Ruang } & \text { kerja } \\
\text { dan } & \text { kuliah } \\
\text { cukup } & \text { dan IT } \\
\text { yang } & \text { belum } \\
\text { layak } & \end{array}$ & LR \\
\hline $\begin{array}{l}\text { Masyaraka } \\
\mathrm{t} \text { (orang } \\
\text { tua, }\end{array}$ & $\begin{array}{l}\text { Keterlibata } \\
\mathrm{n} \\
\text { masyarakat }\end{array}$ & $\begin{array}{l}\text { Keputusan } \\
\text { CSR }\end{array}$ & $\begin{array}{l}\text { Penglibatan } \\
\text { stakeholder }\end{array}$ & $\begin{array}{l}\text { Stakeholder } \\
\text { dilibatkan }\end{array}$ & $\begin{array}{l}\text { Stakeholder } \\
\text { belum } \\
\text { dilibatkan }\end{array}$ & LR \\
\hline
\end{tabular}


Jurnal Pendidikan Akuntansi Indonesia, Vol. XV, No. 2, Tahun 2017

Sukirno DS

$47-62$

\begin{tabular}{|c|c|c|c|c|c|c|}
\hline Pelanggan & Objective & Measure & Initiative & Target & Actual & $\begin{array}{c}\text { Tren } \\
\text { d / } \\
\text { Ket }\end{array}$ \\
\hline \multirow{3}{*}{$\begin{array}{l}\text { pedagang } \\
\text { atau } \\
\text { rekanan, } \\
\text { pihak lain } \\
\text { yang } \\
\text { terkait) }\end{array}$} & $\begin{array}{l}\text { dalam } \\
\text { pengambila } \\
\text { n keputusan } \\
\text { meningkat }\end{array}$ & $\begin{array}{l}\text { Keputusan } \\
\text { penggolonga } \\
\text { n UKT }\end{array}$ & $\begin{array}{l}\text { Penglibatan } \\
\text { orang tua }\end{array}$ & $\begin{array}{l}\text { Orang tua } \\
\text { dilibatkan }\end{array}$ & $\begin{array}{l}\text { Orang tua } \\
\text { dilibatkan }\end{array}$ & $\mathrm{OK}$ \\
\hline & & $\begin{array}{l}\text { Keputusan } \\
\text { penyediaan } \\
\text { fasilitas }\end{array}$ & $\begin{array}{l}\text { Penglibatan } \\
\text { stakeholder }\end{array}$ & $\begin{array}{l}\text { Stakeholder } \\
\text { dilibatkan }\end{array}$ & $\begin{array}{l}\text { Stakeholder } \\
\text { dilibatkan }\end{array}$ & LR \\
\hline & $\begin{array}{l}\text { Keterbukaa } \\
\text { n Informasi } \\
\text { lebih baik }\end{array}$ & $\begin{array}{l}\text { Akses } \\
\text { informasi } \\
\text { penting }\end{array}$ & $\begin{array}{l}\text { Pengembangan } \\
\text { sistem } \\
\text { informasi yang } \\
\text { mudah diakses } \\
\text { stakeholders }\end{array}$ & $\begin{array}{l}\text { Ada sistem } \\
\text { informasi } \\
\text { yang dapat } \\
\text { diakses secara } \\
\text { online dan off } \\
\text { line }\end{array}$ & $\begin{array}{l}\text { Ada sistem } \\
\text { informasi } \\
\text { yang dapat } \\
\text { diakses secara } \\
\text { online dan off } \\
\text { line }\end{array}$ & $\mathrm{OK}$ \\
\hline
\end{tabular}

Matrik di atas sekedar contoh sederhana, artinya rumusan tujuan hingga trend, penempatan sel-selnya bisa saja disesuaikan dengan kebutuhan perguruan tinggi. Dalam hal tertentu dapat terjadi suatu tujuan, ukuran ketercapaian, inisiatif, target, luaran aktual dan trend digunakan secara bersama-sama untuk beberapa atau semua jenis pelanggan (mahasiswa, pegawai, rekanan, pemerintah, dan masyarakat).

\section{SIMPULAN DAN SARAN}

Perguruan tinggi memiliki peran strategis dalam pembangunan sumber daya manusia yang handal. Menilik masih persoalan rendahnya ranking perguruan tinggi dibandingkan perguruan tinggi lain di dunia, rendahnya kualitas sumber daya manusia dibandingkan dengan negara lain, dan tingginya angka pengangguran di Indonesia dapat menjadi indikator masih lemahnya kualitas pengelolaan sumber daya di perguruan tinggi di Indonesia.

Keberadaan sumber daya sangat penting dalam perguruan tinggi karena sumber daya dapat menunjang lahirnya karya, bakat, kreativitas, dorongan dan peran nyata perguruan tinggi bagi pembangunan negara. Tanpa ada sumber daya, tidak mungkin perguruan tinggi akan mati. Keberhasilan dalam mencapai tujuan perguruan tinggi sangat ditentukan oleh kinerja karyawan. Dalam rangka manajemen sumber daya, perguruan tinggi harus merumuskan visi, strategi yang jitu dengan cara terbaik sesuai karakteristik sumber daya yang dimiliki.

Implementasi BSC di perguruan tinggi dapat menjadi sebuah pendekatan strategis dan operasional yang efektif dan efisien apabila diimplementasikan dengan prosedur yang benar dengan melibatkan shareholer dan stakeholer. Aktivitas implementasi BSC dalam perguruan tinggi dimulai dari perumusan visi berbasis SWOT analysis, merumuskan tujuan (objectives), mencari inisiatif startegis dalam mencapai tujuan, menentukan ukuran ketercapaian, dan mengevaluasi ketercapaian tujuan perguruan tinggi.

BSC adalah sebuah pendekatan yang dapat dipilih perguruan tinggi untuk mengelola sumber daya dalam mewujudkan visi dan misinya. BSC menawarkan sebuah cara bagi perguruan tinggi untuk mencapai tujuan secara komprehensif, berimbang, dan terintegrasi antara kinerja keuangan dan non-keuangan, kinerja jangka pendek dan jangka panjang, serta kinerja internal dan kinerja eksternal. 


\section{DAFTAR PUSTAKA}

Anonim. 2012. Upaya Menjawab Masalah Perguruan tinggi di Indonesia. PARLEMENTARIA Edisi $92 \mathrm{TH}$. XLII, 2012 dapat diunduh dari http://www.dpr.go.id/dokpemberita an/majalah-parlementaria/m-922012.pdf pada tanggal 10 Juni 2016.

Akinbowale, M.A., Lourens, M.E, Jinabhai, D.C,. $2014 . \quad$ Employee Performance Measurement and Appraisal Policy in an Organisation. Mediterranean Journal of Social Sciences, Vol 5 No 9, May 2014.

Anwar, Ayu Ardhillah. 2013. Analisis Perspektif Stakeholder Terhadap Implementasi Corporate Social Responsibility (CSR) (Studi Kasus Pada Pt Samsung Electronics Indonesia). Skripsi, Jurusan Akuntansi Fakultas Ekonomi Dan Bisnis Universitas Hasanuddin.

Barney, J. B. \& Hansen, M. H., 1994. Trustworthiness as a Source of Competitive Advantage. Strategic Management Journal, 15(1), pp. 175-190.

Brown, Cindy. 2010. Application of the Balanced Scorecard in Higher Education Opportunities and Challenges. Journal of Research on Technology in Educational. Vol. 43 (2): 40 - 50.

Brown, Cindy. 2012. Application of the Balanced Scorecard in Higher Education Opportunities and Challenges An evaluation of balance scorecard implementation at the College of St. Scholastica. Minnesota: Society for College and University Planning (SCUP).

Brown, Noel and Deegan, Craig. 1998. The Public Disclosure Of Environmental Performance Information - A Dual Test Of Media Agenda Setting Theory And Legitimacy Theory. Accounting \&
Business Riset, Vol. 29, No.1, pp 21-41.

Budimanta, Arif. Dkk. 2008. Corporate Social Responsibility Alternatif bagi Pembangunan Indonesia, Cetakan Kedua. Jakarta: ICSD.

Eisenhardt, Katleen M., 1989. "Agency Theory: An Assessment and Review," Academy of Management Review, Vol. 14 No. $1,1989$.

Fama, Eugene F. 1980. Agency Problems and the Theory of the Firm Author(s): Journal of Political Economy, Vol. 88, No. 2 (Apr., 1980), pp. 288-307.

Ghozali, Imam dan A. Chariri. 2007. Teori Akuntansi. Badan Penerbit Universitas Diponegoro : Semarang.

Hansen, D.R., Guan, Mowen, M.M., Guan, L. 2009. Cost Management. USA: South Western Congage Learning.

Hermawan, Sigit. 2005. Application Of Balance Scorecard As Implementation Tools Strategy In Improving Performance University Muhammadiyah Sidoarjo. Journal of Business Economics and Accounting Ventura, Thn 2008, Vol 11 No. 2

Kaplan, RS and David P Norton. 1996. Using The Balance ScoreCard : Translating Strategy Into Action. Boston Massachusets: Harvard Business School Press.

Kumari, Neeraj. 2011. Balanced Scorecard for Superior Organizational Performance. European Journal of Business and Management, Vol 3, No. 5, 2011.

Lestari, Sri. 2013. Analisis Penilaian Kinerja Lembaga Perguruan tinggi Dengan Metode Balanced Scorecard: Penerapannya Dalam Sistem Manajemen Strategis (Studi Kasus Pada Universitas Brawijaya Malang). 2nd International 
Seminar on Quality and Affordable Education (ISQAE) tahun 2013.

Mulyadi, 2007. Sistem Terpadu Pengelolaan Kinerja Personal Berbasis Balanced Scorecard, Yogyakarta: PP Sekolah Tinggi Ilmu Manajemen YKPN Manajemen.

Musyaddad, Kholid. 2013. Problematika Pendidikan Di Indonesia. Edu-Bio; Vol. 4, Tahun 2013.

Njanja, W. L., Maina, R. N., Kibe, L. K.T., and Njagi, Kageni. 2013. Effect of Reward on Employee Pe rformance: A Case of Kenya Power and Lighting Company Ltd., Nakuru, Kenya. International Journal of Business a nd Management; Vol. 8, No. 21/2013.

Proffitt, Dennis. 2000. Agency Theory as a Basis for Business Ethics dipresentasikan dalam Christian Business Faculty Association October, 2000 diunduh tanggal 10 Juni 2017 dari http://cbfa.org/proffitt_2000_Paper .pdf

Ristekdikti. 2016. Peringkat Universitas di Indonesia. Diunduh tanggal 7 Juni 2017 dari http://ristekdikti.go.id/wpcontent/uploads/2016/02/klasifikas i20151.pdf)

Ronchetti, J.L. 2006.An Integrated Balanced Scorecard Strategic Planning Model for Nonprofit Organizations. Journal of Practical Consulting, Vol. 1 Iss. 1, 2006, pp. 25-35

Rubent, Brent D.. 1999. Toward A Balance Score Card for Higher Education: Rethinking the College and University Excellence Higher Education Indicators Frameworks in a Forum, Fall 1999. Diunduh dari http://www.qci.rutgers.edu pada tanggal 06 Juni 2017.

Sarwoko, Haris. 2010. Analisis Hubungan Antara Prinsipal Dan Agen Pada Perguruan Tinggi Muhammadiyah.
Disertasi, Program Pascasarjana, Departemen Ilmu Administrasi, Fakultas Ilmu Sosial Dan Ilmu Politik, UI, Jakarta

Singgih, Moses L., Damayanti, Kristiana Asih dan Octavia, Renny. 2001. Pengukuran Dan Analisa Kinerja Dengan Metode Balanced Scorecard Di Pt. "X". Jurnal Teknik Industri Vol. 3, No. 2, Desember 2001: 48 - 56 Jurusan Teknik Industri, Fakultas Teknologi Industri, Universitas Kristen Petra.

Sofwan, Ali. 2012. Pengukuran Kinerja Stienu Jepara Dengan Pendekatan Balanced Scorecard Jurnal Dinamika Ekonomi \& Bisnis Vol. 9 No. 1 Maret 2012.

Suryaputra, Verawati dan Yuniawati, Atty. 2012. Perancangan Ukuran Kinerja Pelaksanaan Strategi Berdasarkan Model Balanced Scorecard Pada Perguruan Tinggi. Laporan Penelitian, LPPM Universitas Katolik Prahayangan.

Taufiq, Rohmat. 2012. Penilaian Kinerja Dosen Dalam Bidang Belajar Mengajar Di Fakultas Teknik Universitas Muhammadiyah Tangerang. Faktor Exacta Vol. 5 No. 1 / $2012: 77$ - 85 .

Triyanti, V., Bachtiar, M., dan Rafavy, C.Y. 2013. Redesain Balanced Scorecard Strategy Map Berdasar Konsep KPI dan KRI. Jurnal AlAzhar Indonesia Seri Sains Dan Teknologi, Vol . 2, No. 2, September 2013.

Ullman, A. 1982. Data in Search of a Tjeory: A Critical Examination of the Relationships among Social Performance, Social Disclosure, and Economic Performance of U.S. Firms. Academy of Management Review. Vol.10, No.3, pp 540-557.

Waryanti. 2009. Pengaruh Karakteristik Perusahaan Terhadap Pengungkapan Sosial Pada 
Perusahaan Manufaktur di Bursa Efek Indonesia. Skripsi Fakultas Ekonomi Universitas Diponegoro. Wibisono, Eric. 1999. Tinjauan Atas Paradigma Kualitas Dalam Perguruan tinggi. Indonesia. Unitas, Vol. 7, No. 2, Maret 1999 Agustus 1999, 72-81.

Widiastuti, Tantri dan Ari, Immanuel. 2015. Metode Balance Scorecard Sebagai Tolok Ukur Penilaian Kinerja (Studi Pada PT "X”di Semarang). Jurnal Bisnis Teori \& Implementasi, Vol. 6, No.1, Februari 2015. 